\title{
Tiotropium for Treatment of Stable COPD: A Meta-analysis of Clinically Relevant Outcomes
}

\author{
Abebaw Mengistu Yohannes PhD MSc, Thomas George Willgoss MSc, \\ and Jørgen Vestbo DrMedSci
}

\begin{abstract}
OBJECTIVE: To systematically review recent evidence on the effectiveness of tiotropium versus placebo, ipratropium, and long-acting $\boldsymbol{\beta}_{2}$ agonists on outcomes relevant to patients with stable COPD, including health-related quality of life, dyspnea, exacerbations and hospitalizations. METHODS: Our inclusion criteria for trials were: $\geq 12$ weeks; compared tiotropium to placebo, ipratropium, or longacting $\beta$ agonists; patients $\geq 40$ y old and with stable COPD. Sixteen trials (16,301 patients) met the inclusion criteria. RESULTS: Tiotropium improved health-related quality of life (measured with St George's Respiratory Questionnaire) compared to placebo (odds ratio [OR] 1.61, 95\% CI 1.38-1.88, $P<.001)$ and ipratropium (OR 2.03, 95\% CI 1.34-3.07, $P=.001)$. Tiotropium also improved dyspnea (measured with the Transitional Dyspnea Index) compared to placebo (OR 1.96, 95\% CI 1.58-2.44, $P<.001)$ and ipratropium (OR 2.10, 95\% CI 1.28-3.44, $P=.003)$. Tiotropium decreased the likelihood of an exacerbation (OR $0.83,95 \%$ CI $0.72-0.94, P=.004)$ and related hospitalizations (OR 0.89 , 95\% CI 0.80-0.98, $P=.02)$ but not serious adverse events (OR 1.06, 95\% CI 0.97-1.17, $P=.19$ ), compared to placebo. The cumulative incidence of dry mouth was $7.4 \%$ with tiotropium, compared to $3.9 \%$ with ipratropium, $1.6 \%$ with salmeterol, and $2.0 \%$ with placebo. CONCLUSIONS: In stable COPD, tiotropium showed superior efficacy in improving quality of life and dyspnea, compared to placebo and ipratropium. However, tiotropium's differences with salmeterol were less clear. Key words: dyspnea; exacerbations; hospitalization; meta-analysis; quality of life; tiotropium; COPD. [Respir Care 2011; 56(4):477-487. (C) 2011 Daedalus Enterprises]
\end{abstract}

\section{Introduction}

COPD is a major cause of morbidity, disability, and mortality in old age. COPD was the fifth leading cause of

\footnotetext{
Abebaw Mengistu Yohannes PhD MSc and Thomas George Willgoss MSc are affiliated with the Department of Health Professions, Manchester Metropolitan University, Manchester, United Kingdom. Jørgen Vestbo DrMedSci is affiliated with the Respiratory Research Group, The University of Manchester, Manchester Academic Health Science Centre, University Hospital South Manchester, NHS Foundation Trust, Manchester, United Kingdom.

Dr Vestbo has disclosed relationships with GlaxoSmithKline, AstraZeneca, Boehringer-Ingelheim, Pfizer, and Nycomed. Dr Yohannes and Mr Willgoss have disclosed no conflicts of interest.

Correspondence: Abebaw Mengistu Yohannes PhD MSc, Department of Health Professions, Manchester Metropolitan University, Elizabeth Gaskell Campus, Hathersage Road, Manchester, United Kingdom M13 0JA. E-mail: a.yohannes@mmu.ac.uk.
}

DOI: $10.4187 /$ respcare.00852 death worldwide in 2001 , and is projected to be the third leading cause of death by $2020 .^{1,2}$ Recent findings suggest a 5-year mortality rate, following a COPD exacerbation, as high as $70 \% .^{3}$

The Global Initiative for Chronic Obstructive Lung Disease (GOLD, http://www.goldcopd.org) guidelines advocate long-acting bronchodilators such as tiotropium for patients with moderate to very severe COPD. Tiotropium is a once daily, inhaled long-acting anti-cholinergic drug with a pharmacokinetic selectivity for M3 and M1 receptors. ${ }^{4}$ Tiotropium is the most widely prescribed medication for COPD, and, since its approval in 2002, has been used by more than 10 million users worldwide (http://www. boehringer-ingelheim.com).

In the past few years there have been several large-scale systematic reviews of the efficacy of tiotropium. ${ }^{5-7}$ Previous meta-analyses evaluated a number of variables, including lung function, clinical events, mortality and quality of life. Although analysis of objectively measured physiological variables such as lung function has an important role, it can be 


\section{Meta-analysis of Tiotropium for Treatment of Stable COPD}

argued that those variables are not of primary concern to the patient. Lung function correlates poorly with exercise tolerance and activities of daily living, and narratives by COPD patients suggest that subjective experiences such as dyspnea, emotional well-being, and social functioning may be the most important factors to the patient. ${ }^{89}$ Furthermore, in patients with COPD, dyspnea and health-related quality of life are better predictors of survival than are physiological measures. ${ }^{10}$ In a 5-year, prospective trial with 227 patients with COPD, dyspnea (measured with the Medical Research Council dyspnea scale) was a significant predictor of survival. However, $\mathrm{FEV}_{1}$ was not able to predict survival in that study. ${ }^{11}$ Studies that have examined prognostic indicators for patients admitted with COPD exacerbations found that after one year, quality of life (measured with St George's Respiratory Questionnaire $^{12}$ and the Breathing Problems Questionnaire ${ }^{13}$ ) were strong predictors of mortality, compared to other outcome variables. From a patient's perspective, the effectiveness of a drug is most likely to be judged on outcomes that matter to them in their daily lives, such as ameliorating exertional dyspnea that feels disproportionate to the activity, reducing adverse events, reducing healthcare use, and improving overall quality of life.

A meta-analysis by Barr et al, of studies that included 6,548 patients, found that, compared to placebo, tiotropium reduced exacerbations and frequency of hospitalization and improved patient perceptions of dyspnea and health-related quality of life. ${ }^{5,6}$ That meta-analysis focused more on short-term trials with patients with stable COPD, not designed to detect effects of exacerbations on healthrelated quality of life in long-term trials. Since then there have been several randomized clinical trials that further examined the efficacy of tiotropium in long-term trials. Of particular interest is the Understanding Potential LongTerm Impacts on Function with Tiotropium (UPLIFT) study, which observed the long-term effects of tiotropium therapy in 4 years follow-up in almost 6,000 patients. ${ }^{14}$ Data from that study, alongside others, provides an opportunity for further analysis of tiotropium efficacy from an increasingly large pool of COPD patients. Therefore, we undertook a meta-analysis of randomized controlled trials (RCTs) to evaluate the efficacy of tiotropium on clinically relevant outcomes to patients with COPD, including healthrelated quality of life, dyspnea, adverse events, and clinical events (COPD exacerbations and related hospitalizations) compared to placebo, ipratropium bromide, and longacting $\beta_{2}$ agonists (LABA).

\section{Methods}

\section{Search Strategy and Eligibility Criteria}

We searched MEDLINE, EMBASE, CINAHL, AMED, Web of Knowledge, and the Cochrane Controlled Trials
Register (CENTRAL) for studies published between January 1, 1990 and January 25, 2010), with the key words "tiotropium" OR "tiotropium bromide" OR "Spiriva" AND "COPD" OR "COPD". We also reviewed the reference lists of all the primary studies and reviewed the articles for additional references. We also searched for relevant files from Boehringer Ingelheim (http://trials.boehringer-ingel heim.com/com/home/trialresults/index.jsp) for unpublished data and to explore the overlap between studies.

\section{Study Selection}

The selection criteria were:

- Population: adult patients $\geq 40$ y old with stable COPD consistent with American Thoracic Society/European Respiratory Society ${ }^{10}$ or GOLD diagnostic criteria, ${ }^{4}$ who had not had an exacerbation in the 4 weeks before the study

- Intervention: Tiotropium with placebo, ipratropium bromide, or long-acting $\beta$ agonists (LABA, salmeterol, or formoterol)

- Duration of treatment: Studies that followed patients for $\geq 12$ weeks after randomization

- Design: Parallel-group or crossover RCT

- Primary clinical outcomes: COPD exacerbations; related hospitalizations; health-related quality of life (measured with, for instance, St George's Respiratory Questionnaire) ${ }^{15}$; dyspnea (measured with, for instance, the Transitional Dyspnea Index) ${ }^{16}$; and adverse events (eg, dry mouth, blurred vision, urinary-tract obstruction, and constipation)

- Publication language: English

For the sake of consistency, we followed a Cochrane review $^{5}$ in defining a COPD exacerbation as a complex of respiratory symptoms of new onset, or an increase in at least one of cough, sputum, dyspnea, and wheeze or chest discomfort, that has lasted at least 3 days, and usually associated with a therapeutic intervention.

\section{Data Extraction and Assessment of Methodological Quality}

Titles, abstracts, and citations of potentially relevant studies were independently analyzed by 2 reviewers (AMY and TGW) for inclusion. Disagreements were resolved by discussion with the third author (JV) to determine a group consensus.

Two reviewers (AMY and TGW) extracted data from the selected studies with a standardized protocol. They recorded age, sex, COPD duration of the study (in weeks), 


\section{Meta-analysis of Tiotropium for Treatment of Stable COPD}

smoking history (in pack-years), percentage of current smokers who participated, and COPD severity (measured as mean predicted $\mathrm{FEV}_{1}$ ), and assessed each study for methodological quality. ${ }^{17}$ Randomization, blinding, and reporting of withdrawals and dropouts were rated, using a validated checklist. ${ }^{17} \mathrm{~A}$ score of $<3$ was regarded as methodologically poor quality.

\section{Data Analysis}

Data were analyzed via meta-analysis with statistics software (Stata IC 11, StataCorp, College Station, Texas). We calculated fixed-effect odds ratio (OR) and 95\% CI for dichotomous variables of individual trials. Trials were pooled using the fixed-effect OR. An $\mathrm{I}^{2}$ test was used to test heterogeneity, with values of $25 \%, 50 \%$, and $75 \%$, representative of low, moderate, and high heterogeneity, respectively. $\mathrm{I}^{2}$ can be described as the percentage of total variation between studies that is due to heterogeneity rather than (chance) sampling error. ${ }^{18} \mathrm{~A}$ value of $0 \%$ indicates no observed heterogeneity, and larger values show increasing heterogeneity. When heterogeneity was found (>25\%), a random-effect model was used. We performed a sub-group analysis to determine whether duration of follow-up altered the efficacy of tiotropium in the outcomes of clinical variables of the studies that investigated $12-52$ weeks versus over one-year follow-up. The validated Jadad tool was employed to assess methodological quality. ${ }^{17}$ Significance was set at $P<.05$.

\section{Results}

A total of 107 studies were examined for possible inclusion, of which 91 were excluded, for a number of reasons (Fig. 1). No unpublished studies were found for this review. Sixteen RCTs (16,301 randomized patients) met the inclusion criteria and were selected for analysis. ${ }^{14,19-33}$ The main characteristics of these studies are described in Table 1.

The methodological quality of the included studies was good. Two studies scored 5 out of 5, 9 studies scored 4 out of 5 , and 5 studies scored 3 out of 5 , using the Jadad checklist (see Table 1). ${ }^{17}$

Eleven of the included trials compared tiotropium to placebo; one compared tiotropium to ipratropium ${ }^{20}$; one compared tiotropium to salmeterol ${ }^{22}$; one compared tiotropium to placebo and to salmeterol ${ }^{21}$; one compared tiotropium to placebo, to formoterol, and to a combination of tiotropium and formoterol ${ }^{32}$; and one compared tiotropium (5 $\mu \mathrm{g})$ to tiotropium $(10 \mu \mathrm{g})$, to placebo, and to ipratropium. ${ }^{33}$ The protocols were very similar between the trials. All the studies generally enrolled patients with stable moderate to severe COPD according to the GOLD criteria. All but one study excluded patients with a history of asthma or

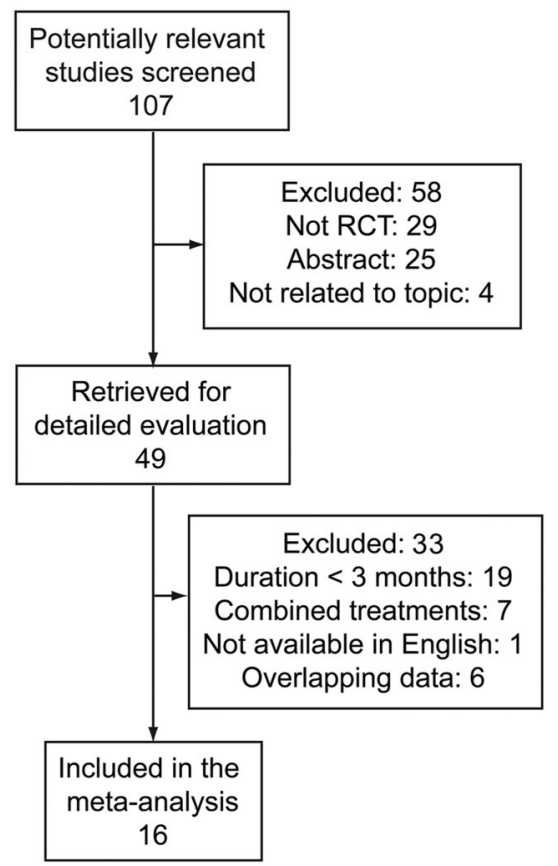

Fig. 1. Identification and selection of studies.

allergic rhinitis. ${ }^{32}$ Seven studies excluded patients with a raised eosinophil count. Eight studies excluded patients with a recent history of myocardial infarct. Seven studies excluded patients with unstable use of corticosteroids.

The demographic characteristics of COPD patients included in the trials were very similar (Table 2). The weighted mean duration of the trials was 95 weeks (mean 37 weeks, range 12-208 weeks). The weighted mean age of participants was 65.1 years (mean $64.5 \mathrm{y}$, range 60 $68 \mathrm{y}$ ), and $76.9 \%$ of participants were male (mean $74.7 \%$, range $48-99 \%$ ). Ten studies reported smoking status, and $33.0 \%$ of the patients were classified as current smokers. The mean smoking history of patients was $45.3 \pm 24.4$ packyears. On average, patients had been diagnosed with COPD for $9.3 \pm 7.7$ years.

\section{Health-Related Quality of Life}

Six studies $(n=6,544)$ examined the proportion of patients who obtained a clinically important change (4unit change) in the St George's Respiratory Questionnaire with tiotropium, compared to placebo. The proportion of patients who achieved a clinically important improvement was greater with tiotropium than with placebo (Fig. 2) and was statistically significant (OR $1.61,95 \%$ CI $1.38-1.88$, $P<.001)$. A similar improvement was observed in one study $(n=443)$ that compared tiotropium to ipratropium (OR 2.03, 95\% CI 1.34-3.07, $P=.001$ ). ${ }^{20}$ There was no significant difference when tiotropium was compared to 


\section{Meta-analysis of Tiotropium for Treatment of Stable COPD}

Table 1. Studies Included in the Present Analysis

\begin{tabular}{|c|c|c|c|c|c|c|}
\hline First Author & Year & $n$ & $\begin{array}{c}\text { Duration } \\
\text { (weeks) }\end{array}$ & Permitted Co-therapies & Interventions and Control & $\begin{array}{c}\text { Quality } \\
\text { Score }\end{array}$ \\
\hline Briggs $^{22}$ & 2005 & 635 & 12 & $\begin{array}{l}\text { Salbutamol, theophylline compounds, inhaled } \\
\text { steroids, modest oral steroids }\end{array}$ & $\begin{array}{l}\text { Tiotropium } 18 \mu \mathrm{g} \text { daily } \\
\text { Salmeterol } 50 \mu \mathrm{g} \text { twice daily }\end{array}$ & 4 \\
\hline Brusasco $^{21}$ & 2003 & 1,207 & 26 & NA & $\begin{array}{l}\text { Tiotropium } 18 \mu \mathrm{g} \text { daily } \\
\text { Salmeterol } 50 \mu \mathrm{g} \text { twice daily } \\
\text { Placebo }\end{array}$ & 4 \\
\hline Casaburi $^{19}$ & 2002 & 921 & 52 & $\begin{array}{l}\text { Albuterol, stable theophylline, inhaled } \\
\text { steroids* }\end{array}$ & $\begin{array}{l}\text { Tiotropium } 18 \mu \mathrm{g} \text { daily } \\
\text { Placebo }\end{array}$ & 3 \\
\hline Casaburi $^{23}$ & 2005 & 108 & 26 & $\begin{array}{l}\text { Albuterol, inhaled steroids, oral steroids, } \\
\text { theophylline }\end{array}$ & $\begin{array}{l}\text { Tiotropium } 18 \mu \mathrm{g} \text { daily } \\
\text { Placebo (plus pulmonary rehabilitation) }\end{array}$ & 4 \\
\hline Chan $^{27}$ & 2007 & 913 & 52 & $\begin{array}{l}\text { Stable oral steroids, }{ }^{*} \text { stable inhaled steroids, } \\
\text { theophylline, non-bronchodilator mucolytic } \\
\text { preparations }\end{array}$ & $\begin{array}{l}\text { Tiotropium } 18 \mu \mathrm{g} \text { daily } \\
\text { Placebo }\end{array}$ & 4 \\
\hline Dusser $^{25}$ & 2006 & 1,010 & 48 & $\begin{array}{l}\text { Short-acting } \beta \text { agonists, stable oral steroids, }{ }^{*} \\
\text { stable inhaled steroids }\end{array}$ & $\begin{array}{l}\text { Tiotropium } 18 \mu \mathrm{g} \text { daily } \\
\text { Placebo }\end{array}$ & 3 \\
\hline Freeman $^{28}$ & 2007 & 395 & 13 & NA & $\begin{array}{l}\text { Tiotropium } 18 \mu \mathrm{g} \text { daily } \\
\text { Placebo }\end{array}$ & 4 \\
\hline Johansson $^{29}$ & 2008 & 224 & 13 & $\begin{array}{l}\text { Salbutamol, oral steroids, and theophylline } \\
\text { only for exacerbations }\end{array}$ & $\begin{array}{l}\text { Tiotropium } 18 \mu \mathrm{g} \text { daily } \\
\text { Placebo }\end{array}$ & 3 \\
\hline Moita $^{30}$ & 2008 & 311 & 13 & $\begin{array}{l}\text { Salbutamol, long-acting } \beta \text { agonists, } \\
\text { theophylline, mucolytics, stable oral } \\
\text { steroids, }{ }^{*} \text { stable inhaled steroids }\end{array}$ & $\begin{array}{l}\text { Tiotropium } 18 \mu \mathrm{g} \text { daily } \\
\text { Placebo }\end{array}$ & 4 \\
\hline Niewoehner ${ }^{24}$ & 2005 & 1,829 & 26 & $\begin{array}{l}\text { Any (except for other open-label } \\
\text { anticholinergic bronchodilators) }\end{array}$ & $\begin{array}{l}\text { Tiotropium } 18 \mu \mathrm{g} \text { daily } \\
\text { Placebo }\end{array}$ & 4 \\
\hline Tashkin $^{14}$ & 2008 & 5,993 & 208 & $\begin{array}{l}\text { Any (except other inhaled anticholinergic } \\
\text { bronchodilators) }\end{array}$ & $\begin{array}{l}\text { Tiotropium } 18 \mu \mathrm{g} \text { daily } \\
\text { Placebo }\end{array}$ & 4 \\
\hline Tonnel $^{31}$ & 2008 & 554 & 39 & $\begin{array}{l}\text { Salbutamol, stable theophylline, stable } \\
\text { mucolytics, stable oral steroids, }{ }^{*} \text { stable } \\
\text { inhaled steroids }\end{array}$ & $\begin{array}{l}\text { Tiotropium } 18 \mu \mathrm{g} \text { daily } \\
\text { Placebo }\end{array}$ & 5 \\
\hline Verkindre $^{26}$ & 2006 & 100 & 13 & $\begin{array}{l}\text { Salbutamol, theophylline, mucolytics, stable } \\
\text { oral steroids, }{ }^{*} \text { inhaled steroids }\end{array}$ & $\begin{array}{l}\text { Tiotropium } 18 \mu \mathrm{g} \text { daily } \\
\text { Placebo }\end{array}$ & 3 \\
\hline Vincken $^{20}$ & 2002 & 535 & 52 & $\begin{array}{l}\text { Salbutamol, stable theophylline, stable oral } \\
\text { steroids,* stable inhaled steroids }\end{array}$ & $\begin{array}{l}\text { Tiotropium } 18 \mu \mathrm{g} \text { daily } \\
\text { Ipratropium } 40 \mu \mathrm{g} 4 \text { times daily }\end{array}$ & 3 \\
\hline Vogelmeier ${ }^{32}$ & 2008 & 847 & 26 & Salbutamol, stable inhaled steroids & $\begin{array}{l}\text { Tiotropium } 18 \mu \mathrm{g}+\text { placebo twice daily } \\
\text { Formoterol } 10 \mu \mathrm{g} \text { twice daily } \\
\text { Tiotropium } 18 \mu \mathrm{g}+\text { formoterol } 10 \mu \mathrm{g} \\
\quad \text { twice daily } \\
\text { Placebo twice daily }\end{array}$ & 5 \\
\hline Voshaar $^{33}$ & 2008 & 719 & 13 & $\begin{array}{l}\text { Salbutamol, stable theophylline, stable } \\
\text { mucolytics, stable oral steroids, }{ }^{*} \text { stable } \\
\text { inhaled steroids }\end{array}$ & $\begin{array}{l}\text { Tiotropium } 5 \mu \mathrm{g}+\text { placebo } 4 \text { times daily } \\
\text { Tiotropium } 10 \mu \mathrm{g}+\text { placebo } 4 \text { times } \\
\quad \text { daily } \\
\text { Ipratropium } 36 \mu \mathrm{g} 4 \text { times daily } \\
\text { Placebo daily }\end{array}$ & 4 \\
\hline
\end{tabular}

salmeterol in one study (OR 1.26, 95\% CI 0.93-1.69, $P=.13) .^{21}$

\section{Dyspnea}

Two studies $(n=1,489)$ examined the proportion of patients who obtained a clinically important change (1unit change) in the Transitional Dyspnea Index with tiotro- pium versus placebo (Fig. 3). There was a statistically significant summary estimate in favor of tiotropium (OR 1.96, 95\% CI 1.58-2.44, $P<.001$ ). There was a similar, statistically significant OR compared to ipratropium (OR 2.10, 95\% CI 1.28-3.44, $P=.003$ ), but there was no significant difference when tiotropium was compared to salmeterol (OR 1.08, 95\% CI 0.80-1.45, $P=.61)$. 
Table 2. Patients demographic characteristics of selected studies

\begin{tabular}{|c|c|c|c|c|c|c|c|c|}
\hline First Author & Year & $\begin{array}{c}\text { Age } \\
(\text { mean } \pm \text { SD y) }\end{array}$ & $\begin{array}{l}\text { Male } \\
(\%)\end{array}$ & $\begin{array}{c}\text { Current } \\
\text { Smoker }(\%)\end{array}$ & $\begin{array}{c}\text { Smoking } \\
\text { History } \\
\text { (mean } \pm \text { SD } \\
\text { pack-years) }\end{array}$ & $\begin{array}{c}\text { COPD } \\
\text { Duration } \\
(\text { mean } \pm \text { SD y) }\end{array}$ & $\begin{array}{c}\mathrm{FEV}_{1} / \mathrm{FVC} \\
(\text { mean } \pm \mathrm{SD} \%)\end{array}$ & $\begin{array}{c}\mathrm{FEV}_{1} \\
\text { (mean } \pm \mathrm{SD} \\
\% \text { predicted) }\end{array}$ \\
\hline Briggs $^{22}$ & 2005 & $64.4 \pm 8.2$ & 67.0 & 35.5 & $55.9 \pm 28.8$ & $9.4 \pm 6.7$ & $43 \pm 10$ & $38 \pm 12$ \\
\hline Brusasco $^{21}$ & 2003 & $64.2 \pm 8.4$ & 76.3 & NA & $43.8 \pm 23.2$ & $9.6 \pm 7.6$ & $43 \pm 10$ & $39 \pm 12$ \\
\hline Casaburi $^{19}$ & 2002 & $65.0 \pm 9.0$ & 64.7 & NA & $61.0 \pm 30.5$ & $8.4 \pm 7.1$ & $46 \pm 12$ & $39 \pm 14$ \\
\hline Casaburi $^{23}$ & 2005 & $66.6 \pm 7.9$ & 56.5 & 24.0 & $58.7 \pm 33.0$ & $9.3 \pm 7.1$ & $43 \pm 11$ & $34 \pm 12$ \\
\hline Chan $^{27}$ & 2007 & $66.9 \pm 8.9$ & 60.0 & 31.0 & $50.6 \pm 24.5$ & $9.9 \pm 8.9$ & $46 \pm 12$ & $39 \pm 14$ \\
\hline Dusser $^{25}$ & 2006 & $64.8 \pm 9.3$ & 88.0 & 25.5 & NA & $8.4 \pm 7.8$ & $55 \pm 12$ & $48 \pm 13$ \\
\hline Freeman $^{28}$ & 2007 & $64.9 \pm 9.1$ & 54.3 & NA & $37.4 \pm 17.3$ & NA & $56 \pm 10$ & $49 \pm 11$ \\
\hline Johansson ${ }^{29}$ & 2008 & $61.6 \pm 8.3$ & 48.0 & 60.0 & $31.5 \pm 12.1$ & $4.8 \pm 4.2$ & $62 \pm 7$ & $73 \pm 13$ \\
\hline Moita $^{30}$ & 2008 & $64.3 \pm 8.7$ & 94.5 & NA & $56.0 \pm 23.6$ & $12.4 \pm 9.2$ & $46 \pm 12$ & $41 \pm 14$ \\
\hline Niewoehner ${ }^{24}$ & 2005 & $67.9 \pm 8.6$ & 99.0 & 30.0 & $68.4 \pm 36.0$ & $12.1 \pm 10.5$ & $48 \pm 11$ & $36 \pm 13$ \\
\hline Tashkin $^{14}$ & 2008 & $64.5 \pm 8.4$ & 74.7 & 29.6 & $48.7 \pm 28.0$ & $9.8 \pm 7.5$ & $42 \pm 11$ & $39 \pm 12$ \\
\hline Tonnel $^{31}$ & 2008 & $64.2 \pm 9.9$ & 86.0 & 27.0 & $43.7 \pm 21.9$ & $8.0 \pm 7.8$ & $55 \pm 11$ & $47 \pm 13$ \\
\hline Verkindre $^{26}$ & 2006 & $60.4 \pm 9.9$ & 94.0 & 28.5 & $43.7 \pm 20.6$ & $9.3 \pm 6.8$ & NA & $35 \pm 9$ \\
\hline Vincken $^{20}$ & 2002 & $64.1 \pm 8.2$ & 85.0 & NA & $33.8 \pm 17.7$ & $11.3 \pm 9.8$ & $46 \pm 10$ & $41 \pm 12$ \\
\hline Vogelmeier $^{32}$ & 2008 & $62.6 \pm 8.9$ & 77.9 & NA & $38.0 \pm 19.6$ & $7.0 \pm 6.4$ & $54 \pm 10$ & $51 \pm 11$ \\
\hline Voshaar $^{33}$ & 2008 & $64.0 \pm 8.8$ & 69.3 & 39.3 & $51.0 \pm 29.0$ & $9.8 \pm 7.8$ & $48 \pm 11$ & $41 \pm 12$ \\
\hline
\end{tabular}

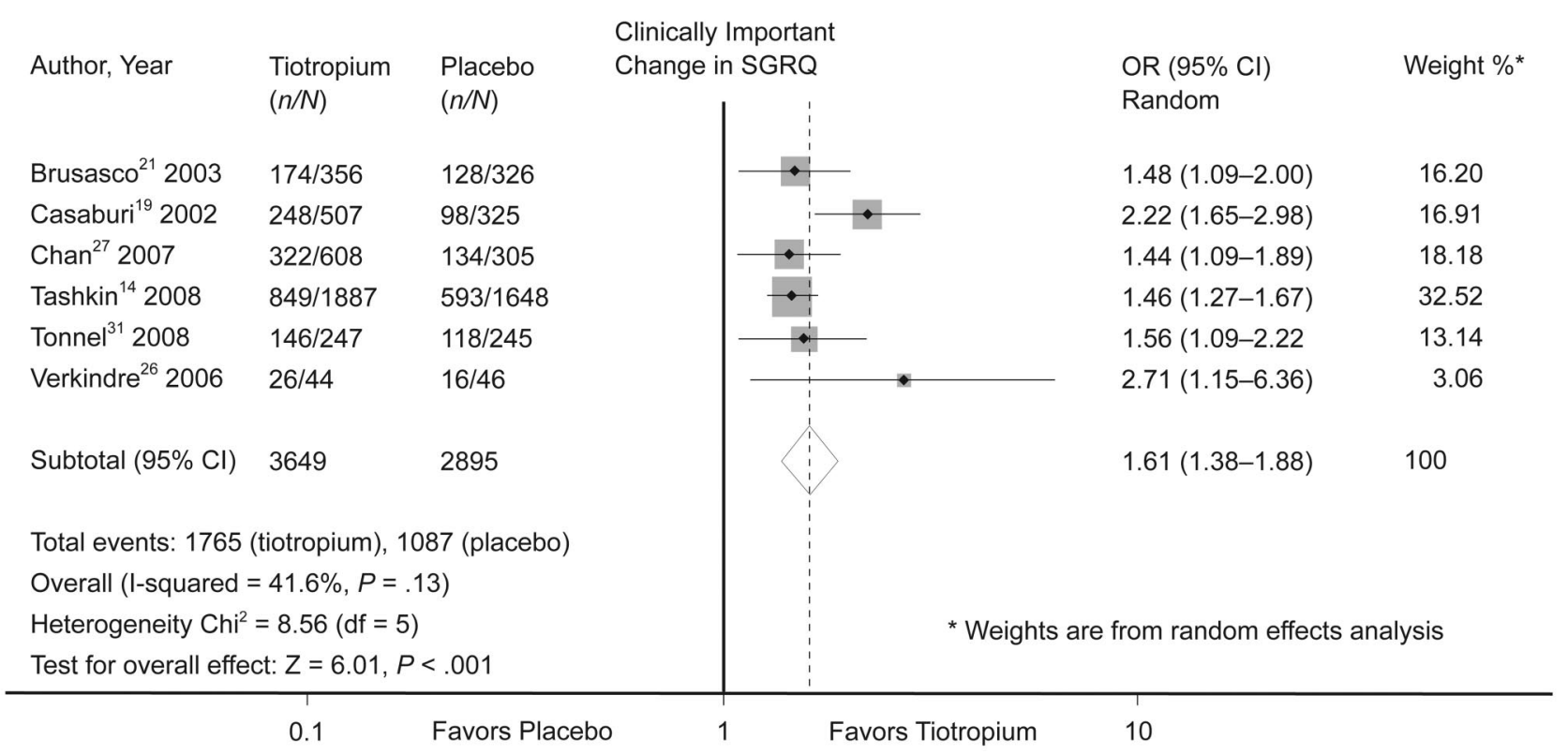

Fig. 2. Effects of tiotropium versus placebo on health-related quality of life, measured with St George's Respiratory Questionnaire.

\section{Exacerbations}

Thirteen studies examined the effect of tiotropium on the proportion of patients who experienced a COPD exacerbation. Tiotropium significantly reduced the odds of an exacerbation in 11 studies $(n=13,124)$ that compared tiotropium to placebo (OR 0.83 , 95\% CI 0.72-0.94,
$P=.004)$ (Fig. 4A) and one study $(n=443)$ that compared tiotropium to ipratropium (OR 0.64, 95\% CI $0.44-0.92, P=.02) .{ }^{20}$ Reductions in exacerbations were observed in 2 studies $(n=1,415)$ that compared tiotropium to salmeterol (Fig. 4B), but that difference was not statistically significant (OR 0.86, 95\% CI $0.67-1.11, P=.25$ ). 


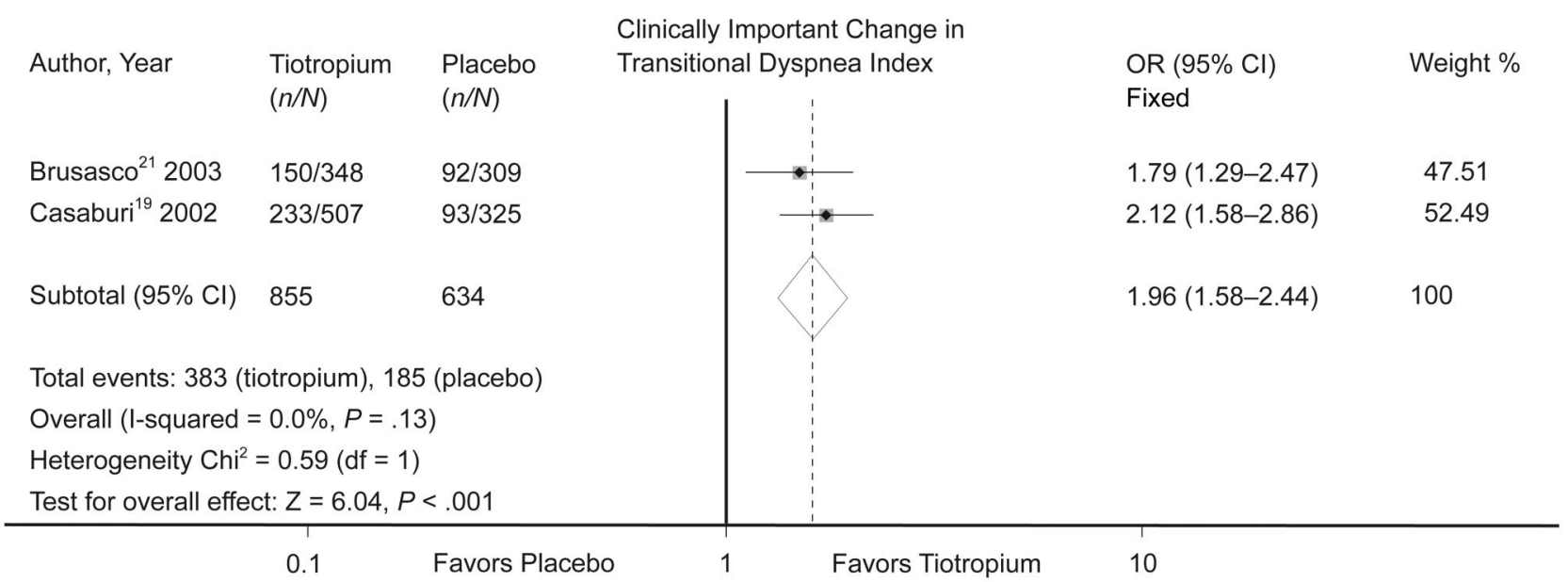

Fig. 3. Effects of tiotropium versus placebo on dyspnea, measured with the Transitional Dyspnea Index.

\section{Exacerbation-Related Hospitalizations}

Nine studies reported the proportion of patients who were hospitalized at least once due to an exacerbation. The summary estimate for the 7 studies $(n=11,844)$ that compared tiotropium to placebo favored tiotropium (Fig. 5A) and the difference was significant (OR 0.89, $95 \%$ CI $0.80-0.98, P=.02$ ). A similar but nonsignificant reduction in the odds of an exacerbation-related hospitalization was also found in 2 studies $(n=1,415)$ that compared tiotropium to salmeterol (OR $0.54,95 \%$ CI $0.29-$ 1.00, $P=.051$ ) (see Fig. 5B), and to lesser extent one study $(n=535)$ that compared tiotropium to ipratropium (OR 0.59, 95\% CI 0.32-1.09, $P=.09$ ). ${ }^{20}$ One study compared tiotropium to formoterol and found a nonsignificant difference (OR 4.98, 95\% CI 0.58-42.96, $P=.15$ )

\section{Adverse Events}

The most commonly reported adverse event was dry mouth: 10 studies reported the incidence of dry mouth. The cumulative incidence was $7.4 \%$ with tiotropium, $3.9 \%$ with ipratropium, $1.6 \%$ with salmeterol, and $2.0 \%$ with placebo. The incidence of dry mouth was over 3 -fold higher in 8 studies $(n=4,998)$ that compared tiotropium to placebo (OR 3.19, 95\% CI 1.79-5.70, $P<.001$ ) (Fig. 6A), in 2 studies $(n=1,415)$ that compared tiotropium to salmeterol (OR 4.60, 95\% CI 2.37-8.93, $P<.001$ ) (see Fig. 6B), and in 2 studies that compared tiotropium to ipratropium (OR 3.09, 95\% CI 1.68-5.66, $P<.001$ ) (see Fig. 6C).

The summary odds estimate for the number of patients who experienced a serious adverse event was not statistically significant when tiotropium was compared to placebo (OR 1.06, 95\% CI 0.97-1.17, $P=.19$ ) (Fig. 7). One study $(n=608)$ that compared tiotropium to salmeterol found a statistically significant lower risk of a serious adverse event with tiotropium (OR $0.39,95 \%$ CI 0.16 $0.95, P=.04)$.

\section{Analysis With Longer Studies Excluded}

To compare the effects of longer-term studies on outcomes, we performed a secondary analysis in which we removed studies longer than one year. ${ }^{14}$ Although there were slight changes in the OR values, significant positive findings remained for health-related quality of life (OR 1.68, 95\% CI 1.44-1.95, $P<.001$ ), exacerbations (OR 0.8, 95\% CI $0.72-0.88, P<.001)$, and exacerbation-related hospitalizations (OR 0.76, 95\% CI 0.62-0.93, $P=.009$ ) when tiotropium was compared to placebo. The summary odds estimate for serious adverse events remained nonsignificant (OR 1.09, 95\% CI $0.88-1.35, P=.43$ ) when tiotropium was compared to placebo.

\section{Discussion}

This systematic review and meta-analysis incorporates 16 RCTs and includes data from 16,301 COPD patients. To our knowledge, to date this is the largest analysis of the efficacy of tiotropium on clinically relevant outcomes in patients with stable COPD. Tiotropium increased the odds of achieving a clinically relevant change on the St George's Respiratory Questionnaire (4 points) and the Transitional Dyspnea Index (one point), compared to both placebo and ipratropium. The odds of an exacerbation or related hospitalization were reduced with tiotropium, compared to placebo, with the mean 37 weeks, which ranged between 12 and 208 weeks of follow-up.

The results of this review are consistent with previous data. ${ }^{5-7}$ Barr et al found that patients using tiotropium were more likely to achieve a clinically important change in St George's Respiratory Questionnaire, compared to pla- 
A

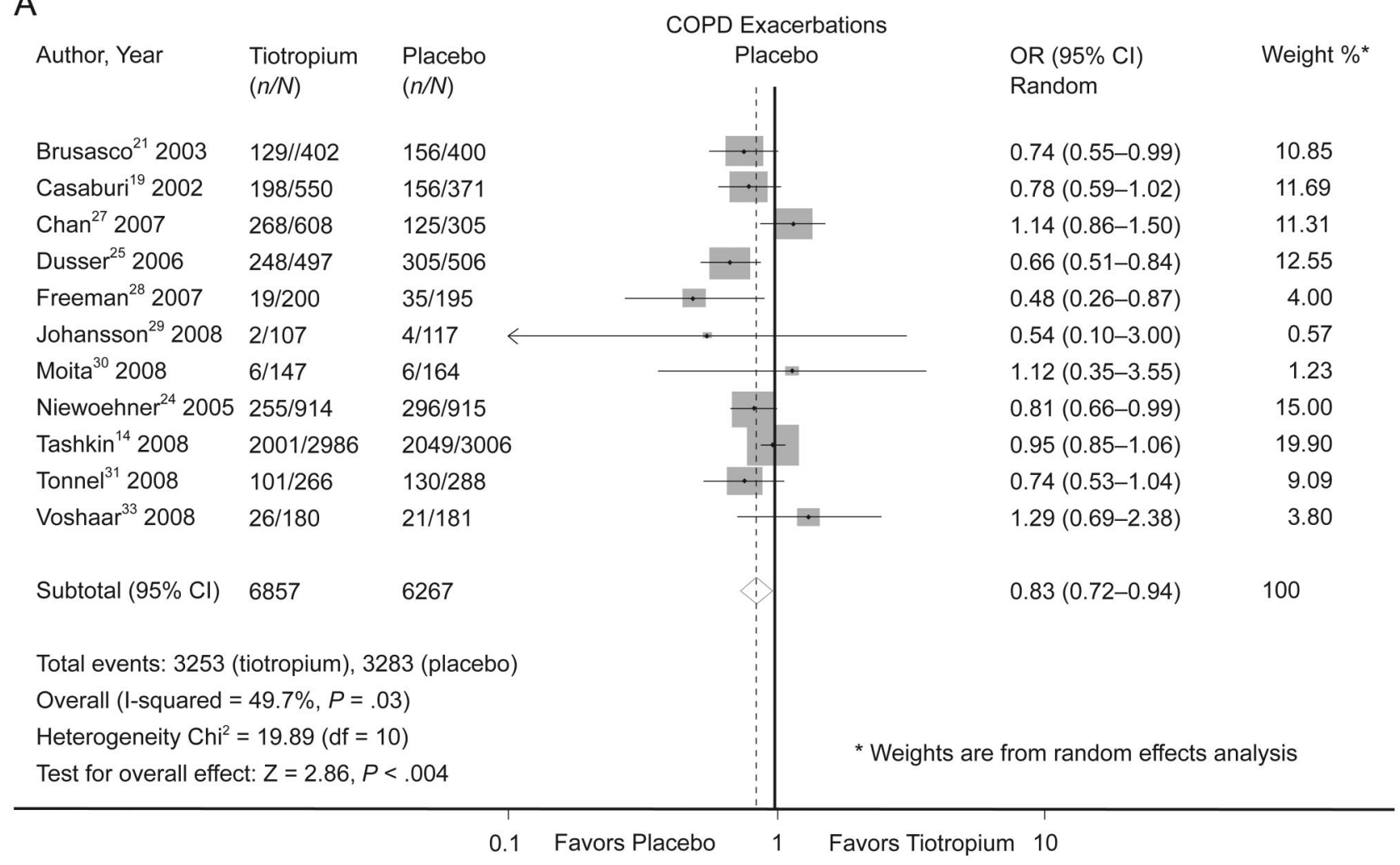

$\mathrm{B}$

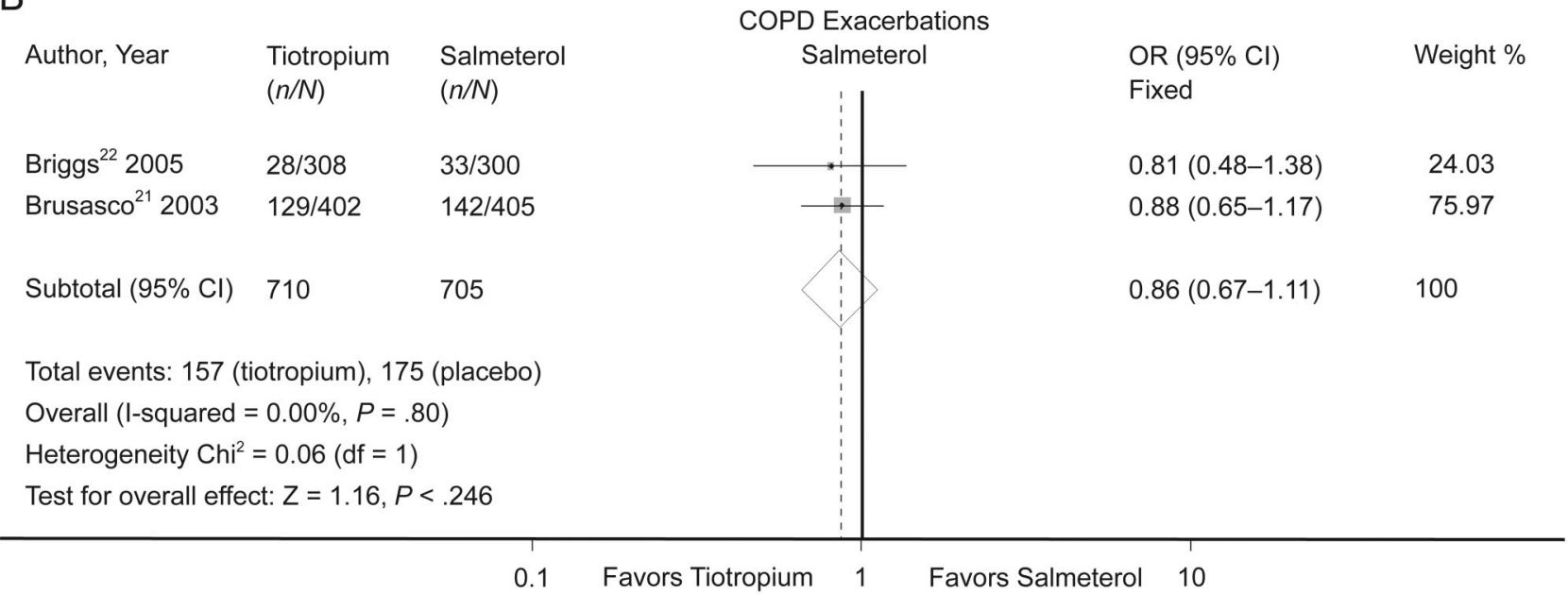

Fig. 4. Effects of tiotropium versus (A) placebo and (B) salmeterol on COPD exacerbations.

cebo (OR 1.92, 95\% CI 1.36-2.71). ${ }^{6}$ This review extends those findings with twice the number of RCTs and over 4 times as many patients than were included by Barr and co-workers (6,544 vs 1,622 COPD patients). ${ }^{6}$ Our findings for clinically important change in dyspnea are the same as in previous reviews, as no new data have become available. ${ }^{5,6}$ Other important findings include the benefit of tiotropium on COPD exacerbations and related hospitalizations. A recent analysis by Rodrigo and Nannini found that, compared to placebo, patients receiving tiotropium had a reduced risk of exacerbation (OR $0.76,95 \%$ CI $0.68-$ 0.87). ${ }^{9}$ The present review also found a significant, but smaller, reduced risk of exacerbation (OR 0.83 , 95\% CI 0.72-0.94). That difference may be attributable to the fact that Rodrigo and Nannini included studies with a shorter treatment duration (one week), whereas we included only studies of at least 12 weeks. ${ }^{7}$ However, despite our stringent inclusion criteria, we included data from 
A

\begin{tabular}{|c|c|c|c|c|c|}
\hline Author, Year & $\begin{array}{l}\text { Tiotropium } \\
(n / N)\end{array}$ & $\begin{array}{l}\text { Placebo } \\
(n / N)\end{array}$ & $\begin{array}{l}\text { Exacerbation-Related } \\
\text { Hospitalizations Placebo }\end{array}$ & $\begin{array}{l}\text { OR }(95 \% \mathrm{Cl}) \\
\text { Fixed }\end{array}$ & Weight \% \\
\hline Brusasco $^{21} 2003$ & $12 / 402$ & $20 / 400$ & $\longrightarrow \quad: 1$ & $0.58(0.28-1.21)$ & 2.42 \\
\hline Casaburi ${ }^{19} 2002$ & $30 / 533$ & $35 / 371$ & $\rightarrow$ & $0.57(0.34-0.95)$ & 4.85 \\
\hline Chan $^{27} 2007$ & $51 / 608$ & $25 / 305$ & & $1.03(0.62-1.69)$ & 3.80 \\
\hline Dusser $^{25} 2006$ & $28 / 500$ & $33 / 510$ & $\rightarrow$ & $0.86(0.51-1.44)$ & 3.84 \\
\hline Niewoehner 242005 & $64 / 914$ & $87 / 915$ & $\rightarrow:$ & $0.72(0.51-1.00)$ & 10.07 \\
\hline Tashkin ${ }^{14} 2008$ & $759 / 2968$ & $811 / 3006$ & $\rightarrow$ & $0.93(0.83-1.04)$ & 74.66 \\
\hline Vogelmier $^{32} 2006$ & $5 / 209$ & $3 / 203$ & + & $1.63(0.39-6.93)$ & 0.37 \\
\hline Subtotal $(95 \% \mathrm{Cl})$ & 6134 & 5710 & i) & $0.89(0.80-0.98)$ & 100 \\
\hline \multicolumn{6}{|c|}{ Total events: 1898 (tiotropium), 2028 (placebo) } \\
\hline \multicolumn{6}{|c|}{ Overall $(\mathrm{I}$-squared $=18.2 \%, P=.03)$} \\
\hline \multicolumn{6}{|c|}{ Heterogeneity $\mathrm{Chi}^{2}=7.34(\mathrm{df}=6)$} \\
\hline \multicolumn{6}{|c|}{ Test for overall effect: $Z=2.35, P<.019$} \\
\hline
\end{tabular}

B

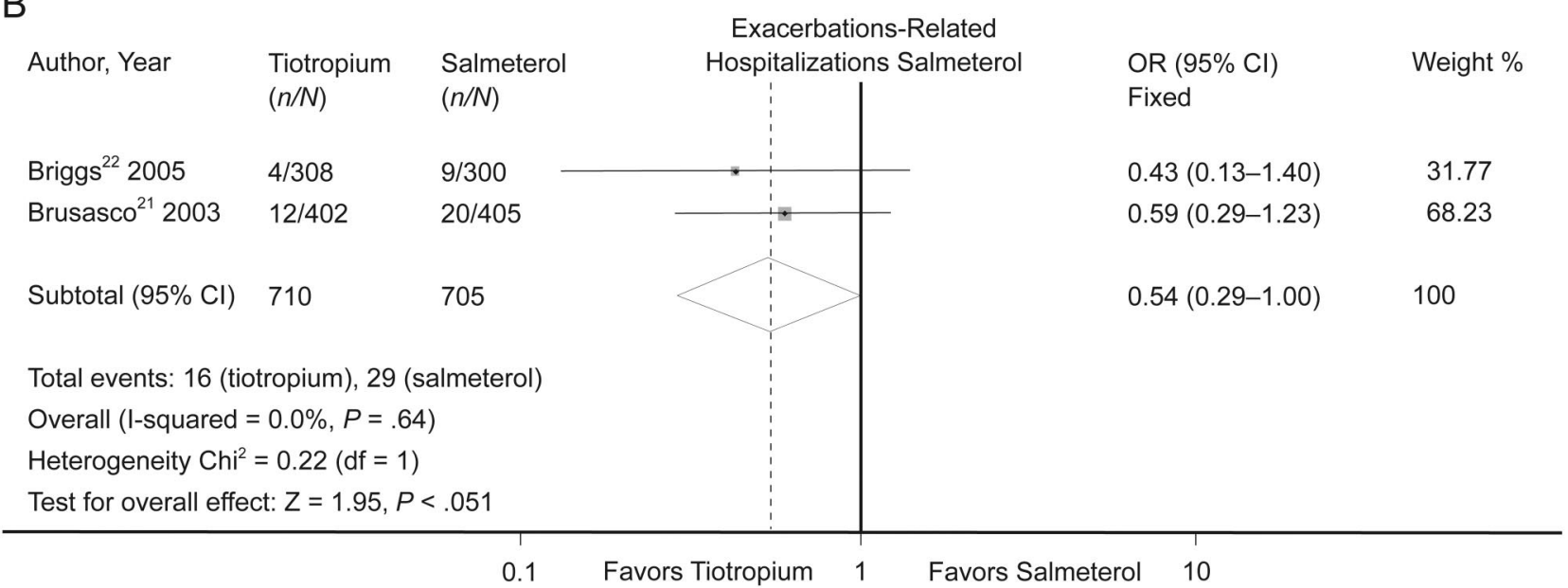

Fig. 5. Effects of tiotropium versus (A) placebo and (B) salmeterol on hospitalizations.

11 studies, compared to 8 in the earlier review. We found that tiotropium also reduced the odds of an exacerbationrelated hospitalization, compared to placebo. Again, this is consistent with earlier reviews. ${ }^{6,7}$

Tiotropium's safety profile is well established, not least from the recent findings in the UPLIFT trial. ${ }^{14}$ Our analysis found no significant difference in serious adverse events between tiotropium and placebo. However, there was a notably high prevalence of dry mouth in patients receiving tiotropium. The cumulative incidence of dry mouth was $7.4 \%$ with tiotropium, compared to $3.9 \%$ with ipratropium, $1.6 \%$ with salmeterol, and $2.0 \%$ with placebo. Previous reviews report a similarly high incidence (11.7\%) of dry mouth with tiotropium, and elevated risks of over 4 times that of placebo. ${ }^{6,7}$

The main strength of our study is that it includes a large pool of COPD patients, which allowed us to perform robust analysis of outcomes relevant to patients and clinicians, in comparison to previous studies.6,7,34 The trials we included used very similar designs and recruited patients with almost identical physiological and socio-demographic data (see Table 2). The trials were also of good quality, with a statistical homogeneity present in most outcomes. However, there were differences in the trial durations, which ranged from 12 weeks to 208 weeks, so our data analysis 
A

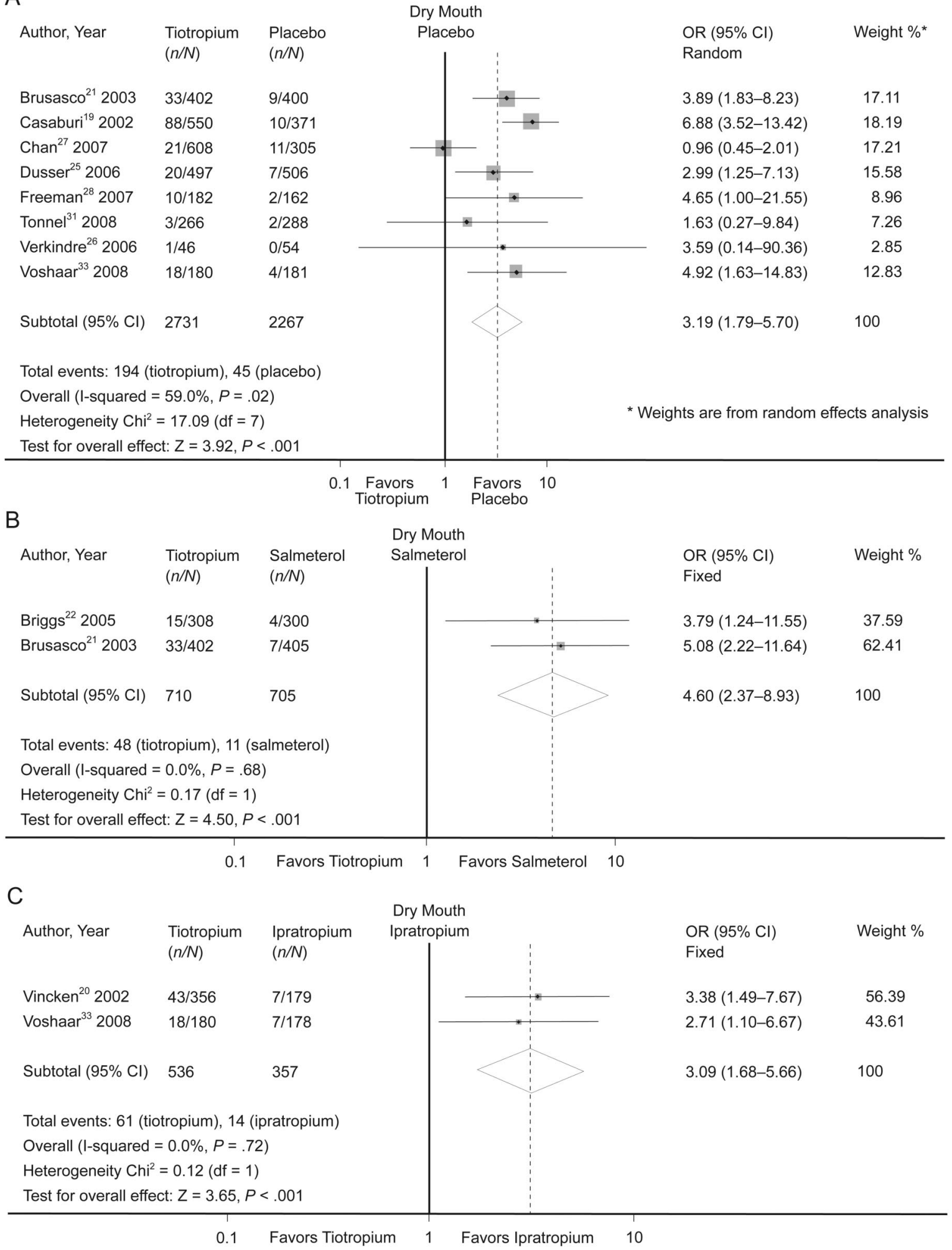

Fig. 6. Effects of tiotropium versus (A) placebo, (B) salmeterol, and (C) ipratropium on dry mouth.

and interpretation should be treated with caution, as certain outcomes may be more likely to occur in longer stud- ies. For example, it is likely that many COPD patients will experience at least one exacerbation in a 4-year period, 


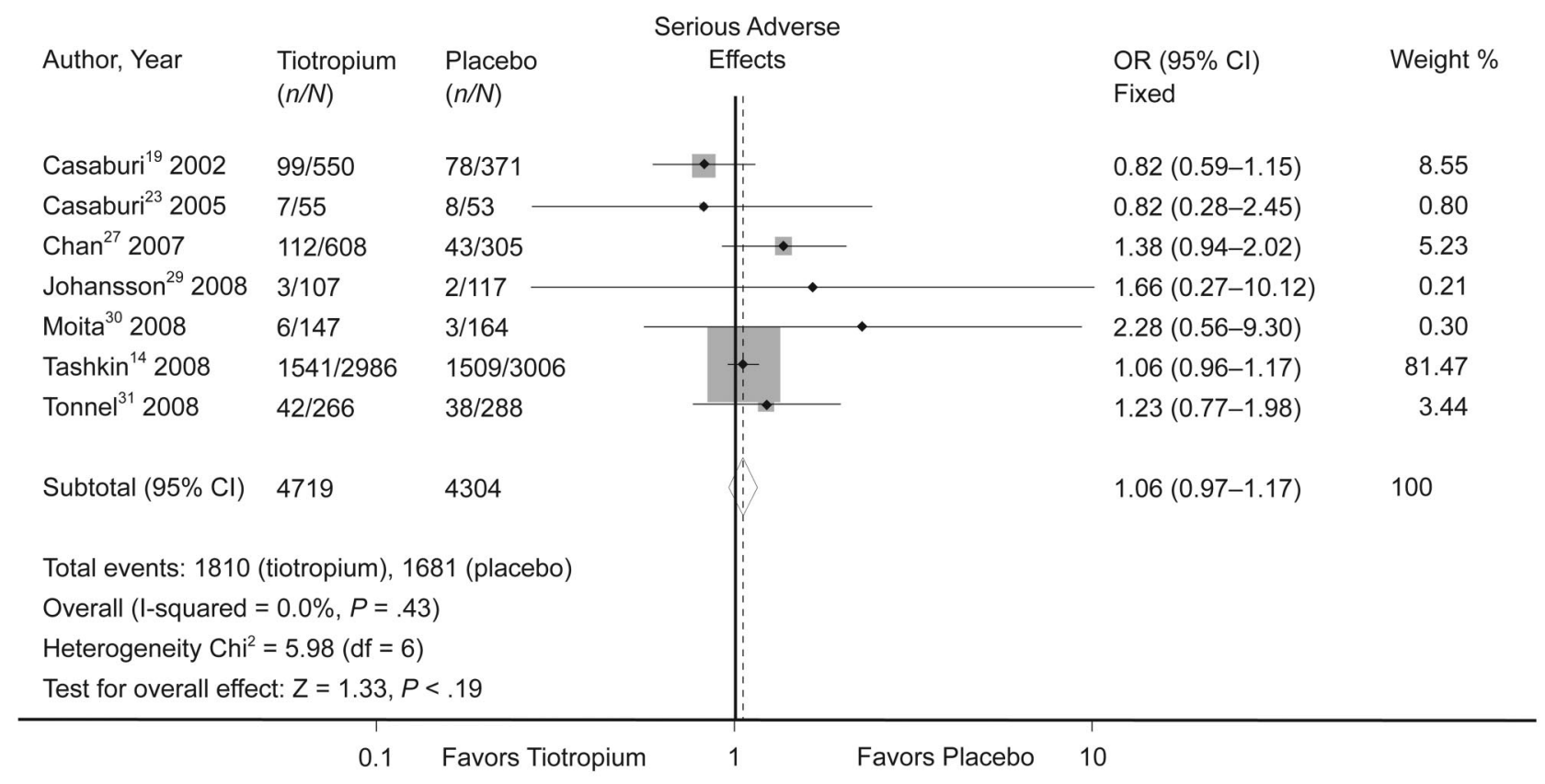

Fig. 7. Effects of tiotropium versus placebo on serious adverse events.

regardless of their medication use. However, our secondary analysis, in which we excluded studies longer than 52 weeks, ${ }^{14}$ found that the lower exacerbation rate and improved quality of life with tiotropium, compared to placebo, remained significant. Dichotomous outcomes, such as the occurrence at least one exacerbation, may not truly reflect the efficacy of a drug, and in such cases an outcome such as number of hospitalizations per patient per year may be an appropriate addition to future reviews. Furthermore, it is important to consider that the included studies had different criteria for the use of co-medications. Caution must be exercised when extrapolating these findings to a clinical population.

\section{Limitations}

First, for the comparisons of tiotropium to ipratropium or LABA, there were often just one or two trials on which to conduct rigorous analysis. This indicates a lack of recent studies of tiotropium versus ipratropium or LABA, so this review does not add any new findings about certain outcomes (eg, dyspnea). Second, we included only published studies that followed patients with COPD over a minimum 3-month period, so we may have missed some unpublished literature. However, we made every attempt to minimize bias by using a systematic search strategy, and we specified the inclusion and exclusion criteria. Furthermore, 2 reviewers independently evaluated selected studies, and a third reviewer was added to reach consensus if necessary. Third, previous meta-analyses reported the problem of double-counting of patients from overlapping publications; we addressed this issue by access- ing the trial database of the manufacturer of tiotropium. ${ }^{6}$ Fourth, there is always a risk of publication bias, because negative or nonsignificant findings are less likely to be published. We have not analyzed this assertion in this review. Finally, our review did not capture sub-analysis of pneumonia-related exacerbations, cardiovascular events, mortality, and intention-to-treat analysis; although these are important, we believe they were adequately reported in 3 recent systematic reviews. ${ }^{34-36}$ Despite these limitations, the long-term efficacy of tiotropium makes it worthy of consideration for first-line therapy and the maintenance of COPD. In addition, in further analysis of the UPLIFT ${ }^{37}$ trial $(n=5,993)$, COPD patients demonstrated that tiotropium increased the time to first exacerbation and time to exacerbation resulting in hospital admission, compared to the control group (OR 0.82 and $0.74,95 \%$ CI $0.75-0.90$ and 0.62-0.88, respectively), and reduced the risk of exacerbation and related hospitalization. ${ }^{34}$

\section{Conclusions}

COPD patients treated with tiotropium had better healthrelated quality of life and dyspnea than patients who received placebo or ipratropium. Tiotropium also significantly reduced the frequency of COPD exacerbations and related hospitalizations. Further studies are needed to compare the efficacy of tiotropium against other treatments, especially when added to a LABA. However, the results of this review and analysis suggest that tiotropium has positive superior effects in the long-term on clinically relevant outcomes in patients with stable COPD. 


\section{Meta-analysis of Tiotropium for Treatment of Stable COPD}

\section{ACKNOWLEDGMENTS}

We are most grateful to Gindo Tampubolon $\mathrm{PhD}$, Institute for Social Change, University of Manchester, Manchester, United Kingdom, for support and statistical advice.

\section{REFERENCES}

1. Pauwels RA, Rabe KF. Burden and clinical features of chronic obstructive pulmonary disease (COPD). Lancet 2004;364(9434):613620.

2. Murray CJ, Lopez AD. Alternative projections of mortality and disability by cause 1990-2020: Global Burden of Disease Study. Lancet 1997;349(9063):1498-1504.

3. Ai-Ping C, Lee KH, Lim TK. In-hospital and 5-year mortality of patients treated in the ICU for exacerbation of COPD. Chest 1997; 128(2):518-524

4. Disse B, Speck GA, Rominger KL, Witek TJ Jr, Hammer R. Tiotropium (Spiriva): mechanistical considerations and clinical profile in obstructive lung disease. Life Sci 1999;64(6-7):457-464.

5. Barr RG, Bourbeau J, Camargo CA. Tiotropium for stable COPD. Cochrane Database Syst Rev 2005;(2):CD002876.

6. Barr RG, Bourbeau J, Camargo CA, Ram FS. Tiotropium for stable COPD: a meta-analysis. Thorax 2006;61(10):854-862.

7. Rodrigo GJ, Nannini LJ. Tiotropium for the treatment of stable COPD: a systematic review with meta-analysis. Pulm Pharmacol Ther 2007; 20(5):495-502.

8. Yohannes AM, Roomi J, Waters K, Connolly MJ. Quality of life in elderly patients with COPD: measurement and predictive factors. Respir Med 1998;92(10):1231-1236.

9. Fraser DD, Kee CC, Minick P. Living with COPD: insiders' perspectives. J Adv Nurs 2006;55(5):550-558.

10. Celli BR, MacNee W. Standards for the diagnosis and treatment of patients with COPD: a summary of the ATS/ERS position paper. Eur Respir J 2004;23(6):932-946.

11. Nishimura K, Izumi T, Tsukino M, Oga T. Dyspnoea is a better predictor of 5-year survival than airway obstruction in patients with COPD. Chest 2002;121(5):1434-1440.

12. Almagro P, Calbo E, Ochoa de Echagüen A, Barreiro B, Quintana S, Heredia JL, Garau J. Mortality after hospitalization for COPD. Chest 2002;121(5):1441-1448.

13. Yohannes AM, Baldwin RC, Connolly MJ. Predictors of 1-year mortality in patients discharged from hospital following exacerbation of COPD. Age Ageing 2005;34(5):491-496.

14. Tashkin DP, Celli B, Senn S, Burkhart D, Kesten S, Menjoge S, Decramer M; UPLIFT Study Investigators. A 4-year trial of triotropium in COPD. N Engl J Med 2008;359(15):1543-1554.

15. Jones PW, Quirk FH, Baveystock CM, Littlejohns P. A self-complete measure of health status for chronic airflow limitation. The St George's Respiratory Questionnaire. Am Rev Respir Dis 1992;145(6): 1321-1327.

16. Mahler DA, Weinberg DH, Wells CK, Feinstein AR. The measurement of dyspnoea: contents, interobserver agreement, and physiologic correlates of 2 new clinical indexes. Chest 1984;85(6):751-758.

17. Jadad AR, Moore RA, Carroll D, Jenkinson C, Reynolds DJ, Gavaghan DJ, McQuay HJ. Assessing the quality of reports of randomized clinical trials: is blinding necessary? Control Clin Trials 1996; 17(1):1-12.

18. Higgins JPT, Thompson SG, Deeks JJ, Altman DG. Measuring inconsistency in meta-analyses. BMJ 2003;327(7414):557-560.

19. Casaburi R, Mahler DA, Jones PW, Wanner A, San PG, ZuWallack $\mathrm{RL}$, et al. A long-term evaluation of once-daily inhaled tiotropium in COPD. Eur Respir J 2002;19(2):217-224.
20. Vincken W, van Noord JA, Greefhorst AP, Bantje TA, Kesten S, Korducki L, Cornelissen PJ. Improved health outcomes in patients with COPD during 1 yr's treatment with tiotropium. Eur Respir J 2002;19(2):209-216

21. Brusasco V, Hodder R, Miravitlles M, Korducki L, Towse L, Kesten S. Health outcomes following treatment for 6 months with once daily tiotropium compared with twice daily salmeterol in patients with COPD. Thorax 2003;58(5):399-404.

22. Briggs DD, Covelli H, Lapidus R, Bhattycharya S, Kesten S, Cassino C. Improved daytime spirometric efficacy of tiotropium compared with salmeterol in patients with COPD. Pulm Pharmacol Ther 2005; 18(6):397-404.

23. Casaburi R, Kukafka D, Cooper CB, Witek TJ Jr, Kesten S. Improvement in exercise tolerance with the combination of tiotropium and pulmonary rehabilitation in patients with COPD. Chest 2005; 127(3):809-817.

24. Niewoehner DE, Rice K, Cote C, Paulson D, Cooper JA Jr, Korducki $\mathrm{L}$, et al. Prevention of exacerbations of COPD with tiotropium, a once-daily inhaled anticholinergic bronchodilator. Ann Intern Med 2005;143(5):317-326.

25. Dusser D, Bravo ML, Iacono P. The effect of tiotropium on exacerbations and airflow in patients with COPD. Eur Respir J 2006; 27(5):547-555

26. Verkindre C, Bart F, Aguilaniu B, Fortin F, Guérin JC, Le Merre C, et al. The effect of tiotropium on hyperinflation and exercise capacity in COPD. Respiration 2006;73(4):420-427.

27. Chan CK, Maltais F, Sigouin C, Haddon JM, Ford GT. A randomised controlled trial to assess the efficacy of tiotropium in $\mathrm{Ca}$ nadian patients with COPD. Can Respir J 2007;14(8):465-472.

28. Freeman D, Lee A, Price D. Efficacy and safety of tiotropium in COPD patients in primary care- the SPiRiva Usual CarE (SPRUCE) study. Respir Res 2007;8:45.

29. Johansson G, Lindberg A, Romberg K, Nordström L, Gerken F, Roquet A. Bronchodilator efficacy of tiotropium in patients with mild to moderate COPD. Prim Care Respir J 2008;17(3):169-175.

30. Moita J, Barbara C, Cardoso J, Costa R, Sousa M, Ruiz J, Santos ML. Tiotropium improves $\mathrm{FEV}_{1}$ in patients with COPD irrespective of smoking status. Pulm Pharmacol Ther 2008;21(1):146-151.

31. Tonnel AB, Perez T, Grosbois JM, Verkindre C, Bravo ML, Brun M. Effect of tiotropium on health-related quality of life as a primary efficacy end point in COPD. Int J Chron Obstruct Pulmon Dis 2008; 3(2):301-310

32. Vogelmeier C, Kardos P, Harari S, Gans SJ, Stenglein S, Thirlwell J. Formoterol mono- and combination therapy with tiotropium in patients with COPD: a 6-month study. Respir Med 2008;102(11): $1511-1520$

33. Voshaar T, Lapidus R, Maleki-Yazdi R, Timmer W, Rubin E, Lowe L, Bateman E. A radomized study of tiotropium Respimat Soft Mist inhaler vs. ipratropium pMDI in COPD. Respir Med 2008;102(1):32-41.

34. Halpin D, Menjoge S, Viel K. Patient-level pooled analysis of the effect of tiotropium on COPD exacerbations and related hospitalisations. Prim Care Respir J 2009;18(2):106-113.

35. Rodrigo GJ, Castro-Rodriguez JA, Nannini LJ, Plaza Moral V, Schiavi EA. Tiotropium and risk for fatal and nonfatal cardiovascular events in patients with COPD: systematic review with meta-analysis. Respir Med 2009;103(10):1421-1429.

36. Singh $\mathrm{S}$, Loke YK, Furberg CD. Inhaled anticholinerigics and risk of major adverse cardiovascular events in patients with COPD: a systematic review and meta-analysis. JAMA 2008;300(12):1439-145.

37. Decramer M, Celli B, Kersten S, Lystig T, Mehra S, Tashkin DP. Effect of tiotropium on outcomes in patients with moderate COPD (UPLIFT): a prescribed subgroup analysis of a randomized controlled trial. Lancet 2009;374(9696):1171-1178. 